\title{
Board of Directors as a Strategic Sparring Partner
}

\author{
by Roman Lombriser \\ (Switzerland)
}

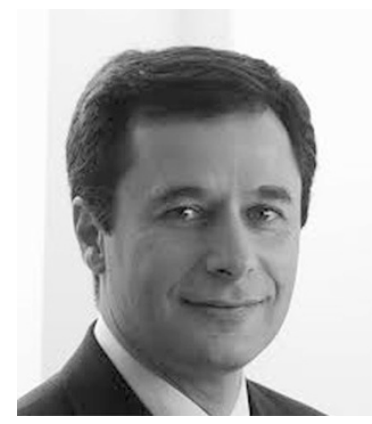

\section{FHNW, Forrer Lombriser \& Partner AG International Center for Corporate Governance}

"Light-Tech" is a traditional SME in Northwestern Switzerland. Its major activities are developing and producing luxury lamps for home and office applications. During the last 20 years, the company has been able to establish itself successfully in the high price segment, focusing mainly on traditional lamp technologies such as incandescent light bulbs, compact fluorescent lamps, and energy-saving halogen bulbs.

The emergence of light-emitting diode (LED) lamps poses a possible major threat to the SME.

LED lamps are based on semiconductor material using protons generated as the source of the light. Major new skills and competencies, together with significant investments, would be required to compete successfully in this new segment.

As a preparation for the annual strategy review with the board of directors, the CEO together with his management team updates—as usual — the SWOT matrix. In the threat quadrant, the team mentions the new technology; however, in the strategy proposal for the next 3 years, the managers consider a forced investment in new energy-saving lamps based on the traditional technologies as more urgent and promising.

In September, the board of directors and the top management team met for a 2-days strategy seminar off-site. The chairman and several of the other directors, who all were experienced strategist and successfully led several companies for many years, had bad feelings about the issue of technology replacement. Contrary to the top management team, the board of directors were not convinced that the breakthrough of the new LED technology in the market was still far away. 
Preparing for the September seminar, the chairman was wondering how to lead the strategy discussion without demotivating the management team by imposing too strongly his view on the executives while at the same time fulfilling the obligation of warning top management about critical threats.

Question: What do you recommend the chairman to do to solve this issue in an effective way?

\section{$1 \quad$ What Happened in Reality?}

Together with the executive team, the board of directors performed a scenario analysis for about 3 hours. In this analysis, the team varied two main external drivers of change:

- Customer acceptance of the new technology: very fast vs. gradual vs. slow adoption of the new LED technology by the main customer segments

- State-funded financial subsidies for the new LED technology: high vs. medium vs. low (as today)

In the subsequent evaluation, the board assessed the likelihood for the most probable scenario, the "gradual change scenario" at around 50\%. The more pessimistic scenario (fast acceptance of the new technology, strong funding by the government) received a probability of still 30\%. The following discussion of the implications in the case of the pessimistic scenario becoming reality revealed that the company could not afford the risk of not preparing for this threat.

The board requested the top management team to formulate a precautionary strategy which much better prepares the SME for the pessimistic scenario. Four months later, in the January meeting, the board approves a plan, submitted by top management, that asks for a continued investment in the traditional energy-saving lamps, yet not with as much funding as the top management team was originally planning for. Instead, the plan also included measures to push the implementation of the new business segment for LED products, in cooperation with an external partner.

\section{$2 \quad$ Results}

- Two years later, the pessimistic scenario reveals itself as reality. The replacement of the traditional products by the new LED technology occurs much faster than most top managers expected.

- Thanks to the more robust strategy as consequence of the collective scenario analysis, the SME can establish itself successfully in the new LED segment. 


\section{$3 \quad$ Key Lessons Learned}

- By performing a scenario analysis together with the top management team, the board of directors were able to play an important role as strategic partner, without interfering too much in operative details ("constructive sparring partner").

- Developing different scenarios of the future and coming up with possible strategic answers can help to prevent dangerous "one-way strategies" and opens up the strategic perspectives of both the board as well as of top management.

Open Access This chapter is licensed under the terms of the Creative Commons Attribution 4.0 International License (http://creativecommons.org/licenses/by/4.0/), which permits use, sharing, adaptation, distribution and reproduction in any medium or format, as long as you give appropriate credit to the original author(s) and the source, provide a link to the Creative Commons licence and indicate if changes were made.

The images or other third party material in this chapter are included in the chapter's Creative Commons licence, unless indicated otherwise in a credit line to the material. If material is not included in the chapter's Creative Commons licence and your intended use is not permitted by statutory regulation or exceeds the permitted use, you will need to obtain permission directly from the copyright holder.

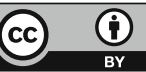

